\title{
Prediction of seed-yield potential of common bean populations
}

\author{
Ângela de Fátima Barbosa Abreu ${ }^{1}$, Magno Antonio Patto Ramalho ${ }^{2}$ and João Bosco dos Santos ${ }^{2}$ \\ ${ }^{1}$ Embrapa Arroz e Feijão/UFLA, Departamento de Biologia, Lavras, MG, Brazil. \\ ${ }^{2}$ Universidade Federal de Lavras (UFLA), Departamento de Biologia, Lavras, MG, Brazil.
}

\begin{abstract}
Earliest possible prediction of seed-yield potential of autogamous crop populations increases breeding program efficiency by saving time and resources. Alternatives for obtaining seed-yield predictions were compared by evaluating four common-bean populations in $F_{1}$ and $F_{2}$ generations together with the parents. Mean components ( $m$ $+a^{\prime}$ and d) and variances were estimated. The potential of each population was predicted by using both these and the Jinks and Pooni (1976) procedure, which allows probability estimation of each population of originating lines surpassing a determined standard. Estimate efficiency was determined by evaluating performances of $62 F_{5: 7}$ families from each population. Mean component $m+a$ ' estimates obtained for the $F_{1}$ and $F_{2}$ generations proved efficient in predicting seed yield of $F_{7}$ generation lines as did $d$ for estimate variance among $F_{7}$ generation families. In addition, the Jinks and Pooni (1976) procedure proved efficient in early prediction of common bean population genetic potentials, especially when using the $m+a$ ' estimate.
\end{abstract}

Key words: choice of parents, heritability, mean components, common bean, Phaseolus vulgaris L.

Received: March 6, 2002; accepted: July 22, 2002.

\section{Introduction}

The success of an autogamous-plant breeding program depends on the choice of populations capable of produce progeny with desired trait combinations. The ideal segregating population makes it possible to select lines with performance superior to that of the parents. Careless choice can cause resource and time loss. Procedures making possible early discarding of unpromising populations have been the objective of several studies (Singh and Urrea, 1995; Oliveira et al., 1996).

The methodologies used to achieve this goal can be separated into two categories (Baenziger and Peterson, 1991). The first involves procedures using information on the parents, e.g., average performance, coancestry coefficient, and multivariate analysis to estimate genetic divergence. The second group uses information about progeny behavior from diallel crosses. The methodologies first mentioned rule out simultaneously obtaining information about mean components and variance. The Jinks and Pooni (1976) procedure estimates the probability of obtaining lines surpassing a given standard in the $\mathrm{F}_{\infty}$ generation, considering the average and variance of an earlier generation. This methodology has already been used to evaluate soybean (Triller, 1994) and common bean (Otubo et al., 1996)

Send Correspondence to A. de F. B. Abreu. Departamento de Biologia, Universidade Federal de Lavras, C.P. 37, 37200-000 Lavras, MG, Brazil. E-mail: afabreu@ufla.br. populations. However, information confirming its efficiency is limited.

The aim of this study was to evaluate the efficacy of the Jinks and Pooni (1976) procedure and to find alternatives to improve this method in prediction of the seed-yield potential of common bean populations.

\section{Material and Methods}

Four segregating populations were chosen from a diallel cross based on divergence among parents and for the purpose of selecting lines with grain type acceptable to consumers. The parents are described in Table I.

The $F_{1}$ and $F_{2}$ generations were obtained from Carioca x Brasil-2, Carioca x Flor de Mayo, IPA-7419 x A-114 and Brasil-2 $\times$ A-114 crosses. A portion of $\mathrm{F}_{2}$ seed was advanced by the bulk method to $F_{5}$, from which generation individual plants were harvested. The $\mathrm{F}_{5: 6}$ families were again sown and harvested in bulk to obtain the $\mathrm{F}_{5: 7}$ families. Two field experiments were conducted. In the first, the performance of the parents, $F_{1}$ and $F_{2}$ generations was evaluated in field experiments in Lavras, MG, Brazil (21 ${ }^{\circ} 14^{\prime}$ ' $\mathrm{S}$ latitude and $45^{\circ} 00^{\prime} \mathrm{W}$ longitude) in July, 1996 . The statistical design was randomized complete blocks with five replications. The five parents (Table I), the four $\mathrm{F}_{1}$ generations and $16 \mathrm{~F}_{2}$ (four from each cross) were evaluated. The plots consisted of one two-meter row spaced at $0.5 \mathrm{~m}$ with 15 seeds sown per meter. The equivalent of $400 \mathrm{~kg} / \mathrm{ha}$ of the formula 
Table I - Traits of common bean cultivars used in the cross.

\begin{tabular}{lllclc}
\hline Cultivar & Domestication center & Race & Growth habit & \multicolumn{2}{c}{ Grain } \\
\cline { 5 - 6 } & & & & Color & Size \\
\hline Carioca & Meso-America & Mesoamerica & III & Beige with brown striation & $\mathrm{S}$ \\
Brasil-2 & Meso-America & Mesoamerica & I & Beige & S \\
IPA-7419 & Meso-America & Mesoamerica & III & Beige & S \\
Flor de Mayo & Meso-America & Jalisco & IV & Tan and pink & M \\
A-114 & Meso-America & Durango & III & Variegated burgundy & M \\
\hline
\end{tabular}

${ }^{1 /} \mathrm{S}$ : small (weight of 100 seeds less than $25 \mathrm{~g}$ ); M: medium (weight of 100 seeds between 25 and $40 \mathrm{~g}$ ).

4-14-8 of $\mathrm{N}, \mathrm{P}_{2} \mathrm{O}_{5}$ and $\mathrm{K}_{2} \mathrm{O}$ fertilizer was used in sowing and $150 \mathrm{~kg} / \mathrm{ha}$ ammonia sulphate sidedressing 20 days after emergence. The culture received overhead irrigation. Other cultural practices were those typical for this crop.

The plants were harvested individually and the grain yield obtained in $\mathrm{g} / \mathrm{plant}$. The phenotypic variance $\left(\sigma_{\mathrm{F}}^{2}\right)$ of each plot was estimated and, later, the average phenotypic variance of plots that received identical treatment in the different replications. Genetic variance $\left(\sigma_{\mathrm{G}_{i}}^{2}\right)$ of the $\mathrm{i}^{\text {th }}$ population was estimated by $\sigma_{\mathrm{G}_{\mathrm{i}}}^{2}=\sigma_{\mathrm{F}_{2 \mathrm{i}}}^{2}-\sigma_{\mathrm{E}_{\mathrm{i}}}^{2}$, in which: $\sigma_{\mathrm{F}_{2 \mathrm{i}}}^{2}$ is the average phenotypic variance of the $F_{2}$ generation from $i^{\text {th }}$ population, and $\sigma_{\mathrm{E}_{\mathrm{i}}}^{2}$, the average environmental variance of $i^{\text {th }}$ population. Variances of parental cultivars $\left(\sigma_{\mathrm{P}_{\mathrm{li}}}^{2}\right.$ or $\left.\sigma_{\mathrm{P}_{2 \mathrm{i}}}^{2}\right)$ and $\mathrm{F}_{1}$ generation $\left(\sigma_{\mathrm{F}_{1}}^{2}\right)$ were due to environmental variability. Therefore, the environmental variance $\left(\sigma_{\mathrm{E}_{\mathrm{i}}}^{2}\right)$ was estimated as: $\sigma_{\mathrm{E}_{\mathrm{i}}}^{2}=\left(\sigma_{\mathrm{P}_{\mathrm{l}_{\mathrm{i}}}}^{2}+\sigma_{\mathrm{P}_{2 \mathrm{i}}}^{2}+\sigma_{\mathrm{F}_{\mathrm{li}_{\mathrm{i}}}}^{2}\right) / 3$.

Estimates of mean components $\mathrm{m}+\mathrm{a}$ ' and $\mathrm{d}$ were obtained. The term $\mathrm{m}$ represents the phenotypic mean of all possible lines in the $\mathrm{F}_{\infty}$ generation from crosses between completely divergent parents. The term a' is the sum of effects of fixed loci in the parents, i.e., loci containing identical alleles; and $d$ is heterozygote deviation in relation to the parents' mean. The weighted least square method (Rowe and Alexander, 1980) used the following model: $\left(\overline{\mathrm{P}}_{1_{\mathrm{i}}}+\overline{\mathrm{P}}_{2_{\mathrm{i}}}\right) / 2=\mathrm{m}+\mathrm{a}^{\prime}{ }_{\mathrm{i}} ; \overline{\mathrm{F}}_{1_{\mathrm{i}}}=\mathrm{m}+\mathrm{a}_{\mathrm{i}}{ }_{\mathrm{i}}+\mathrm{d}_{\mathrm{i}} ; \overline{\mathrm{F}}_{2_{\mathrm{i}}}=\mathrm{m}+\mathrm{a}_{\mathrm{i}}{ }_{\mathrm{i}}+$ $1 / 2 \mathrm{~d}_{\mathrm{i}}$, in which $\overline{\mathrm{P}}_{1_{\mathrm{i}}}$ and $\overline{\mathrm{P}}_{2_{\mathrm{i}}}$ are the means of parents 1 and 2 , respectively, from the $\mathrm{i}^{\text {th }}$ population, and $\bar{F}_{1_{i}}$ and $\bar{F}_{2_{i}}$ are the means of $F_{1}$ and $F_{2}$ generations, respectively, from the $i^{\text {th }}$ population. Estimates population $\mathrm{m}+\mathrm{a}$ ' were compared by the t test $(\alpha=0.05)$.

Population seed yield potentials were evaluated using the Jinks and Pooni (1976) procedure. The probability of a population to generate lines surpassing a given standard was estimated; it corresponds to the area to the right of a value in abscissa of the normal distribution. Using the properties of a standardized normal distribution, we calculated this area estimating the variable $\mathrm{Z}$ by $\mathrm{Z}=\left[\mathrm{x}-\left(\mathrm{m}+\mathrm{a}^{\prime}\right)\right] / \mathrm{s}$, in which $\mathrm{x}$ is the line mean considered as standard $(\overline{\mathrm{L}})$, which in this case was the Carioca cultivar; $\mathrm{m}+\mathrm{a}$ ' is the line mean seed yield in the $\mathrm{F}_{\infty}$ generation. In a model without dominance, the mean seed yield of the $\mathrm{F}_{2}$ generation $\left(\overline{\mathrm{F}}_{2 \mathrm{i}}\right)$ should equal line mean in the $\mathrm{F}_{\infty}$ generation. Term $\mathrm{s}$ is the phenotypic standard deviation among the lines. Genetic variance among the lines $\left(\sigma_{\mathrm{L}}^{2}\right)$ corresponds to twice the additive genetic variance $\left(\sigma_{\mathrm{A}}^{2}\right)$ present in the $\mathrm{F}_{2}$ generation. Considering a model without dominance and epistasis, the phenotypic variance of $\mathrm{F}_{2}\left(\sigma_{\mathrm{F}_{2}}^{2}\right)$ contains $\sigma_{\mathrm{A}}^{2}+\sigma_{\mathrm{E}}^{2}$. Therefore, $2 \sigma_{A}^{2}=2 \sigma_{F_{2}}^{2}-2 \sigma_{E}^{2}$. Assuming that the environmental variance among the lines is similar to that of the $\mathrm{F}_{2}$ generation, then $\mathrm{s}=\sqrt{\sigma_{\mathrm{L}}^{2}}=\sqrt{2 \sigma_{\mathrm{A}}^{2}+\sigma_{\mathrm{E}}^{2}}=\sqrt{2 \sigma_{\mathrm{F}_{2}}^{2}-\sigma_{\mathrm{E}}^{2}}$. Thus, for each $i^{\text {th }}$ population, $Z_{i}=\frac{\left(\overline{\mathrm{L}}-\overline{\mathrm{F}}_{2_{\mathrm{i}}}\right)}{\sqrt{2 \sigma_{\mathrm{F}_{2_{\mathrm{i}}}}^{2}-\sigma_{\mathrm{E}_{\mathrm{i}}}^{2}}}$.

The $\mathrm{F}_{5: 7}$ families were evaluated in the other field experiment, conducted in Lavras and Patos de Minas, (18 $35^{\circ}$ S latitude and $46^{\circ} 31^{\prime} \mathrm{W}$ longitude), $\mathrm{MG}$, Brazil at the same time and under the same conditions as the previous one. The statistical design was a $16 \times 16$ lattice with three replications. Sixty two families from each population, the five parents, and three additional control cultivars were evaluated.

Seed yield was measured in g/plot, which was analyzed for variance combined over locations and with a further joint analysis, considering the following statistical model with all variables random, except the average: $\mathrm{Y}_{\mathrm{ijks}}=\mathrm{m}+\mathrm{p}_{\mathrm{i}}+\mathrm{l}_{\mathrm{s}}+\mathrm{pl}_{\mathrm{is}}+\mathrm{r}_{\mathrm{j}(\mathrm{s})}+\mathrm{b}_{\mathrm{k}(\mathrm{js})}+\mathrm{e}_{\mathrm{ijks}}$; in which $\mathrm{Y}_{\mathrm{ijks}}$ : production of $\mathrm{i}$ family, in the $\mathrm{k}$ block, $\mathrm{j}$ replication, s location; $\mathrm{m}$ : general mean; $\mathrm{p}_{\mathrm{i}}$ : effect of $\mathrm{i}$ family, being $\mathrm{i}=1,2, \ldots$, $256 ; 1_{\mathrm{s}}$ : effect of $\mathrm{s}$ location, being $\mathrm{s}=1,2 ; \mathrm{pl}_{\mathrm{is}}$ : effect of the interaction of $i$ family with $\mathrm{s}$ location; $\mathrm{r}_{\mathrm{j}(\mathrm{s})}$ : effect of $\mathrm{j}$ replication within $\mathrm{s}$ location; $\mathrm{b}_{\mathrm{k}(\mathrm{j}) \mathrm{s})}$ : effect of $\mathrm{k}$ block, within $\mathrm{j}$ replication and $\mathrm{s}$ location; $\mathrm{e}_{\mathrm{ijks}}$ : average effective error.

Based on expected mean squares, the estimates of genetic and phenotypic variances among family averages from the $i^{\text {th }}$ crossing were obtained. Broad sense heritability $\left(\mathrm{h}^{2} \mathrm{i}\right)$ was estimated using the Vencovsky and Barriga (1992) methodology. Upper and lower limits of confidence intervals at $1-\alpha=0.95$ probability level were estimated for heritabilities (Knapp et al., 1985). 


\section{Results and Discussion}

The estimate of $\mathrm{m}+\mathrm{a}$ ' corresponds to the mean of all possible lines of a given cross in the $F_{\infty}$ generation (Vencovsky, 1987). In this study, $\mathrm{m}+\mathrm{a}$ ' values varied from $7.72 \mathrm{~g} /$ plant, Brasil-2 x A-114 population, to $13.36 \mathrm{~g} / \mathrm{plant}$, Carioca x Flor de Mayo population (Table II). All contrasts in these estimates were significant. Therefore, one can infer that the Carioca $x$ Flor de Mayo population will produce lines with a higher average in the $\mathrm{F}_{\infty}$ generation.

Contrary to the estimates for $\mathrm{m}+\mathrm{a}$ ', largest $\mathrm{d}$ estimates were obtained in the IPA $7419 \times$ A-114 and Brasil-2 x A-114 populations (Table II). Dominance for seed yield was demonstrated in these populations by the superiority of the $F_{1}$ generation's average in relation to the parent and $F_{2}$ generation averages, in agreement with several studies reporting heterosis for the common bean grain yield (Ghaderi et al., 1984; Gutiérrez and Singh, 1985; Nienhuis and Singh, 1986).

Since the d estimate refers to the contribution of heterozygous loci in relation to the parents' mean, assuming all loci have equal effects, one can infer that IPA $7419 \mathrm{x}$ A-114 and Brasil-2 x A-114 populations had the greatest number of heterozygous loci. Therefore, more variation in the $F_{2}$ and later generations would be expected from these two populations. The estimates of $\mathrm{F}_{2}$ genetic variance estimates presented in Table II support this observation. The Carioca $\mathrm{x}$ Brasil 2 population d estimate was null, and in this case the $F_{2}$ generation genetic variance estimate was negative. Therefore it could be considered null indicating absence of genetic variation, that is, the most loci were fixed and $\mathrm{d}$ is null.

Most procedures evaluating the potential of segregating populations only consider average performance, with little or no emphasis on population variability. This estimation requires data on individual plants in the $\mathrm{F}_{2}$ generation. This process can be very laborious and is usually associated with high error. The results here obtained show that, in the presence of dominance, the d estimate could substitute the genetic variance estimate. Since this parameter is a mean component of any trait, it is, thus, estimable with greater precision than variance, without having to obtain data from individual plants. However, the $\mathrm{F}_{1}$ and $\mathrm{F}_{2}$ generations must be evaluated simultaneously, because producing a suffi- cient number of $\mathrm{F}_{1}$ seed for crops such as the common bean where manual crossings are laborious and may be difficult, an alternative is to evaluate the $\mathrm{F}_{2}$ and $\mathrm{F}_{3}$ generation performances (Oliveira et al., 1996).

Estimates of $\mathrm{m}+\mathrm{a}$ ' and d provide plant breeders with information needed to decide which segregating populations will be more promising. As already mentioned, $\mathrm{m}+\mathrm{a}$ ' corresponds to the mean of $\mathrm{n}$ lines in the $\mathrm{F}_{\infty}$ generation, and $\mathrm{d}$ would be the variation indicator among the lines. The ideal is a segregating population with high $\mathrm{m}+\mathrm{a}$ ' and d values, because this population should produce lines with high mean yields and great variation, an important goal for plant breeders.

Analysis of variance of $\mathrm{F}_{5: 7}$ family seed yield is presented in Table III. Significant difference occurred among the lines for all populations, except Carioca $\mathrm{x}$ Brasil-2. Family $\mathrm{x}$ location interactions were significant only in Carioca x Flor de Mayo and A-114 x Brasil-2 populations. The broad-sense heritability estimates presented in Table IV varied from $18.5 \%$ for the Carioca $\mathrm{x}$ Brasil- 2 cross, to $52.4 \%$ for the Brasil-2 x A-114 cross. In selecting more promising populations, plant breeders usually take heritability estimates into consideration. However, the results of this study point out populations having higher heritability and populations presenting the lowest average among all families (Table V). Therefore, heritability alone does not guarantee breeding program success, since it could be associated with inferior average yield. Populations with high mean yields and sufficient variability are the most promising.

Correlations between $\mathrm{d}$ and $\mathrm{h}^{2}$ and between $\mathrm{m}+\mathrm{a}$, and the mean yield of $\mathrm{F}_{5: 7}$ families were estimated. Between $\mathrm{d}$ and $\mathrm{h}^{2}$, it was positive and high $(\mathrm{r}=0.95)$, indicating association of $\mathrm{d}$ with genetic variance. The $\mathrm{m}+\mathrm{a}$ ' estimate had 0.97 correlation with the mean yield of $\mathrm{F}_{5: 7}$ families, supporting the theory that this estimate reflects family average in further generations (Vencovsky, 1987).

For the Jinks and Pooni (1976) procedure, 'Carioca' was considered as the productive cultivar standard, besides being the most widely cultivated in Brazil. The probability estimates for obtaining lines superior to the Carioca cultivar are presented in Table VI. Probability estimates were obtained using two procedures: considering the $F_{2}$

Table II - Mean yield, in g/plant, of the parents, $\mathrm{F}_{1 \mathrm{i}}$ and $\mathrm{F}_{2 \mathrm{i}}$ generations and estimates of the genetic variance of the $\mathrm{F}_{2}\left(\sigma_{\mathrm{G}_{\mathrm{i}}}^{2}\right)$ generation and mean components $\left(\mathrm{m}+\mathrm{a}^{\prime}{ }_{\mathrm{i}}\right.$ and $\mathrm{d}_{\mathrm{i}}$ ) of each $\mathrm{i}$ population.

\begin{tabular}{lccrrrr}
\hline Crossings & $\left(\overline{\mathrm{P}}_{1}+\overline{\mathrm{P}}_{2}\right) / 2$ & $\overline{\mathrm{F}}_{1}$ & $\overline{\mathrm{F}}_{2}$ & $\sigma_{\mathrm{G}_{\mathrm{i}}}$ & $\mathrm{m}+\mathrm{a}^{\prime}{ }_{\mathrm{i}}$ & $\mathrm{d}_{\mathrm{i}}$ \\
\hline Carioca x Brasil-2 & 12.054 & 12.087 & 11.439 & -7.699 & $11.552(0.618)^{1 /}$ & $0.110(1.080)$ \\
Carioca x F.Mayo & 13.864 & 14.144 & 12.478 & 4.553 & $12.997(1.376)$ & $0.127(2.394)$ \\
IPA-7419 x A-114 & 10.256 & 13.619 & 10.700 & 12.605 & $9.726(1.015)$ & $2.918(1.878)$ \\
Brasil-2 x A-114 & 7.904 & 12.854 & 9.812 & 7.472 & $7.720(0.418)$ & $4.597(0.832)$ \\
\hline
\end{tabular}

${ }^{1 /}$ Standard error. 
Table III - Joint analysis of variance of seed yield, in $\mathrm{g} / \mathrm{plot}$, of $\mathrm{F}_{5: 7}$ families from the crossings among common bean cultivars, evaluated in Lavras-MG and Patos de Minas-MG, Brazil.

\begin{tabular}{|c|c|c|c|}
\hline Source of variance & $\begin{array}{l}\text { Degrees of } \\
\text { freedom }\end{array}$ & $\begin{array}{l}\text { Mean } \\
\text { square }\end{array}$ & $\mathrm{p}^{1 /}$ \\
\hline Locations (L) & 1 & 1053156.540 & 0.000 \\
\hline Families (F) & 255 & 10349.989 & 0.000 \\
\hline Carioca $\times$ Brasil-2 & 61 & 4033.602 & 0.135 \\
\hline Carioca x Flor de Mayo & 61 & 7663.353 & 0.000 \\
\hline A-114 x IPA-7419 & 61 & 6548.079 & 0.000 \\
\hline A-114 x Brasil-2 & 61 & 10103.986 & 0.000 \\
\hline Parents (P) & 4 & 12301.155 & 0.005 \\
\hline Checks (C) & 2 & 9015.645 & 0.068 \\
\hline Between crossings (B) & 3 & 259936.589 & 0.000 \\
\hline $\mathrm{B} v s . \mathrm{P}$ & 1 & 16396.906 & 0.027 \\
\hline $\mathrm{B}$ and $\mathrm{P} v s . \mathrm{C}$ & 1 & 46524.390 & 0.000 \\
\hline $\mathrm{F} \times \mathrm{L}$ & 255 & 4483.613 & 0.001 \\
\hline (Carioca $\times$ Brasil-2) $\times$ L & 61 & 3286.569 & 0.521 \\
\hline (Carioca $x$ Flor de Mayo) x L & 61 & 5668.220 & 0.000 \\
\hline (A-114 x IPA-7419) x L & 61 & 3253.034 & 0.543 \\
\hline (A-114 x Brasil-2) x L & 61 & 4806.424 & 0.017 \\
\hline $\mathrm{P} \times \mathrm{L}$ & 4 & 2182.118 & 0.627 \\
\hline $\mathrm{C} \times \mathrm{L}$ & 2 & 14948.070 & 0.012 \\
\hline B x L & 3 & 19525.501 & 0.000 \\
\hline$(\mathrm{B} v s . \mathrm{P}) \times \mathrm{L}$ & 1 & 6273.792 & 0.171 \\
\hline (B and $\mathrm{P} v s . \mathrm{C}) \times \mathrm{L}$ & 1 & 1977.285 & 0.443 \\
\hline Mean effective error & 930 & 3338.104 & \\
\hline Mean & & 264.9 & \\
\hline Coefficient of variation (\%) & & 21.8 & \\
\hline
\end{tabular}

1/Level of probability used in the F test.

generation mean or the $\mathrm{m}+\mathrm{a}$ ' estimate as the mean of lines in the $\mathrm{F}_{\infty}$ generation. Since dominance in seed yield was detected, the $\mathrm{F}_{2}$ generation mean, besides $\mathrm{m}+\mathrm{a}$, will have half the contribution of loci in heterozygosis $\left(\overline{\mathrm{F}}_{2}=\mathrm{m}+\mathrm{a}+\right.$ $1 / 2 \mathrm{~d}$ ). However, the differences in probability estimates were not pronounced, except for the Brasil-2 x A-114 population, where the highest $\mathrm{d}$ estimate was obtained. Use of the $\mathrm{F}_{2}$ generation mean to represent the $\mathrm{F}_{\infty}$ average was proposed by Jinks and Pooni (1976) and has been used by some researchers (Triller, 1994; Otubo et al., 1996). Although dominance for seed yield is reported frequently, most gene action in the common bean is additive (Nienhuis and Singh, 1988; Ramalho et al., 1988; Abreu, 1989; Takeda, 1990). Therefore, the $\mathrm{F}_{2}$ generation mean can be considered, because even with an inflated probability estimate, the choice of best populations should not be affected. However, the $\mathrm{m}+\mathrm{a}$ ' estimate can be easily obtained and does not depend on occurrence of dominance.

The population with the greatest chance of producing lines superior to the Carioca cultivar came from the Carioca
Table IV - Genetic variance $\left(\sigma_{\mathrm{G}_{\mathrm{i}}}^{2}\right)$ and broad sense heritability $\left(\mathrm{h}^{2}{ }_{\mathrm{i}}\right)$ with their respective confidence intervals, grain yield ( $\mathrm{g} / \mathrm{plot}$ ) of $\mathrm{F}_{5: 7}$ lines from four common bean populations evaluated in Lavras-MG and Patos de Minas-MG, Brazil.

\begin{tabular}{lcccc}
\hline Crossings & $\sigma_{\mathrm{G}_{\mathrm{i}}}^{2}$ & $\mathrm{~h}^{2}{ }_{\mathrm{i}}(\%)$ & $\mathrm{LL}_{\mathrm{i}}{ }^{1 /}$ & $\mathrm{UL}_{\mathrm{i}}{ }^{2 /}$ \\
\hline Carioca x Brasil-2 & 124.506 & 18.52 & -35.23 & 50.91 \\
Carioca x Flor de Mayo & 332.522 & 26.03 & -22.76 & 55.43 \\
IPA-7419 x A-114 & 549.174 & 50.32 & 17.55 & 70.07 \\
Brasil-2 x A-114 & 882.927 & 52.43 & 21.05 & 71.34 \\
\hline
\end{tabular}

${ }^{1 /}$ Lower limit of the heritability estimate; ${ }^{2 /}$ Upper limit of the heritability estimate.

Table $\mathbf{V}$ - Mean grain yield (g/plot) of the parents $\left(\mathrm{P}_{1_{\mathrm{i}}}\right.$ e $\left.\mathrm{P}_{2_{\mathrm{i}}}\right)$ and $\mathrm{F}_{5: 7}$ families from each $\mathrm{i}^{\text {th }}$ population and percentage of families superior to the Carioca cultivar (PSC). Lavras-MG and Patos de Minas-MG, Brazil.

\begin{tabular}{lcccc}
\hline Crossings & $\overline{\mathrm{P}}_{1_{\mathrm{i}}}$ & $\overline{\mathrm{P}}_{2_{\mathrm{i}}}$ & Families & PSC \\
\hline Carioca x Brasil-2 & 246.3 & 243.3 & 285.8 & 16.1 \\
Carioca x Flor de Mayo & 246.3 & 283.9 & 286.4 & 29.0 \\
IPA-7419 x A-114 & 266.4 & 165.6 & 254.9 & 4.8 \\
Brasil-2 x A-114 & 243.3 & 165.6 & 231.8 & 0.0 \\
\hline
\end{tabular}

Table VI - Mean yield $\left(\overline{\mathrm{F}}_{2_{\mathrm{i}}}\right)$, in g/plant, and estimates of phenotypic variance $\left(\dot{\Phi}_{\mathrm{F}_{2}}^{2}\right)$ of $\mathrm{F}_{2}$ generation, environmental variance $\left(\dot{\Phi}_{\mathrm{E}_{\mathrm{i}}}^{2}\right)$ and probability (\%) of obtaining lines superior in yield to the Carioca cultivar (PSC).

\begin{tabular}{lccccc}
\hline Crossings & $\overline{\mathrm{F}}_{2_{\mathrm{i}}}$ & $\dot{\Phi}_{\mathrm{F}_{\mathrm{i}}}^{2}$ & $\dot{\Phi}_{\mathrm{E}_{\mathrm{i}}}^{2}$ & $\mathrm{PSC}^{\underline{1} \underline{ }}$ & $\mathrm{PSC}^{2} \underline{\underline{ }}$ \\
\hline Carioca x Brasil-2 & 11.439 & 40.152 & 47.851 & 21.67 & 23.81 \\
Carioca x F.Mayo & 12.478 & 58.494 & 53.941 & 33.32 & 37.42 \\
IPA-7419 x A-114 & 10.700 & 46.433 & 33.828 & 24.92 & 21.52 \\
Brasil-2 x A-114 & 9.812 & 38.531 & 31.058 & 18.46 & 11.37 \\
\hline
\end{tabular}

1/Probability of obtaining lines superior in yield to the Carioca cultivar, using $\overline{\mathrm{F}}_{\mathrm{i}_{\mathrm{i}}}$.

2/Probability of obtaining lines superior in yield to the Carioca cultivar, using $\mathrm{m}_{\mathrm{i}}+\mathrm{a}{ }_{\mathrm{i}}$

$\mathrm{x}$ Flor de Mayo population; the worst was the Brasil-2 $\mathrm{x}$ A-114 population (Table VI). These results agree with estimates of specific combining ability obtained by Abreu et al. (1999) and with the previously reported $\mathrm{m}+\mathrm{a}$ ' estimates.

Mean grain yield varied from 221.9 to $357.9 \mathrm{~g} /$ plot in the Carioca x Brasil-2 population; from 177.9 to 344.9 $\mathrm{g} / \mathrm{plot}$ for the Carioca $\times$ Flor de Mayo population; 181.9 to $316.9 \mathrm{~g} /$ plot for IPA-7419 x A-114, and from 146.8 to $305.8 \mathrm{~g} / \mathrm{plot}$ for the Brasil-2 x A-114 population. The highest mean, considering all lines, was observed in the Carioca $\mathrm{x}$ Flor de Mayo population and the lowest in the Brasil-2 $\mathrm{x}$ A-114 population (Table V), again agreeing with the $m+a$ ' estimates (Table II).

Twenty-nine percent of the $\mathrm{F}_{5: 7}$ families from the Carioca x Flor de Mayo crossing had mean yields greater 
than the Carioca average $(\mathrm{p} \leq 0.05)($ Table $\mathrm{V})$, similar to the estimate previously reported by Jinks and Pooni (1976) (Table VI). In the case of the Brasil-2 x A-114 population, no $\mathrm{F}_{5: 7}$ lines had seed yield superior to the Carioca cultivar (Table V), in agreement with the previous results and showing that the probability of obtaining lines superior to this cultivar would be lower in this population (Table VI).

Comparison of the observed probability of obtaining lines superior in yield to 'Carioca' with expected probability (Tables V and VI) shows agreement in the results obtained, as already mentioned. However, the estimated probability was always superior. For this reason, some factors must be considered. The first is the relatively small 62 lines sample used to represent the population. Although no reports exist in the literature about the number of lines that should represent a segregating population of autogamous plants, Fouilloux and Bannerot (1988) showed that the population need not be large for selective success. They then suggested, after evaluating 10,000 families, that the maximum number of favorable alleles accumulated in the best line would be 32 out of 40 . This number would not be much lower if only 100 families had been evaluated, which could accumulate, in the best line, 27.9 favorable alleles. The second factor is $\mathrm{F}_{2}$ generation genetic variance which contains not only additive variance, but also dominance and epistasis. Therefore, the line phenotypic deviation standard becomes inflated and, consequently, so does the estimated probability. In conclusion, despite the slight discrepancy observed, the Jinks and Pooni (1976) procedure proved an excellent alternative in early selection of autogamous crop segregating populations, especially if used with the $\mathrm{m}+\mathrm{a}$ ' estimate.

\section{Acknowledgement}

Research was supported by Fundação de Amparo à Pesquisa do Estado de Minas Gerais (FAPEMIG), Minas Gerais, Brasil.

\section{References}

Abreu A de FB (1989) Avaliação de progênies de feijoeiro do cruzamento "Carioca 80" x "Rio Tibagi" em diferentes densidades de plantio. M.S. thesis, Escola Superior de Agricultura de Lavras, Lavras.

Abreu A de FB, Ramalho MAP and Santos JB dos (1993) Capacidade de combinação de cultivares de feijão de diferentes conjuntos gênicos. In: IV Reunião Nacional de Pesquisa de Feijão, Londrina, PR, Resumos, 120.

Abreu A de FB, Ramalho MAP and Ferreira DF (1999) Selection potential for seed yield from intra- and inter-racial populations in common bean. Euphytica 108:121-127.

Baenziger PS and Peterson CJ (1991) Genetic variation: Its origin and use for breeding self-pollinated species. In: Stalker HT and Murphy JP (eds.) Plant breeding in the 1990's. North Carolina State University, Raleigh, pp 69-100.

Fouilloux G and Bannerot H. (1988) Selection methods in the common bean (Phaseolus vulgaris L.). In: Gepts P (ed) Genetics resources of Phaseolus beans. Kluwer Academic Publishers, Dordrecht, pp 503-541.

Ghaderi A, Adams MW and Nassib AM (1984) Relationship between genetic distance and heterosis for yield and morphological traits in dry edible bean and faba bean. Crop Sci 24:37-42.

Gutiérrez JA and Singh SP (1985) Heterosis and inbreeding depression in dry bush beans, Phaseolus vulgaris L. Can J P1 Sci 65:243-249.

Jinks JL and Pooni HS (1976) Predicting the properties of recombinant inbred lines derived by single seed descent. Heredity 36:253-266.

Knapp SJ, Stroup WW and Ross WM (1985) Exact confidence intervals for heritability on a progeny mean basis. Crop Sci 25:192-194.

Nienhuis J and Singh SP (1986) Combining hability analyses and relationships among yield, yield components and architectural traits in dry bean. Crop Sci 26:21-27.

Nienhuis J and Singh SP (1988) Genetics of seed yield and its components in common bean (Phaseolus vulgaris L.) of Middle-American origin. I. General combining ability. Plant Breeding 101:143-154.

Oliveira LB de, Ramalho MAP, Abreu A de FB and Ferreira DF (1996) Alternative procedures for parent choice in a breeding program for the common bean (Phaseolus vulgaris L). Braz J Genet 19:611-615.

Otubo ST, Ramalho MAP, Abreu A de FB and Santos JB dos (1996) Genetic control of low temperature tolerance in germination of the common bean (Phaseolus vulgaris L.). Euphytica 89:313-317.

Ramalho MAP, Santos JB dos and Pereira Filho IA (1988) Choice of parents for dry bean (Phaseolus vulgaris L.) breeding. I. Interation of mean components by generation and by location. Rev Bras Genet 11:391-400.

Rowe KE and Alexander WL (1980) Computations for estimating the genetic parameters in joint-scaling tests. Crop Sci 20:109-110.

Singh SP and Urrea AC (1995) Inter- and intraracial hybridization and selection for seed yield in early generations of common bean, Phaseolus vulgaris L. Euphytica 81:131-137.

Takeda C (1990) Avaliação de progênies de feijoeiro do cruzamento "ESAL 501" $\mathrm{x}$ "A 354 em diferentes densidades de plantio. M.S. thesis, Escola Superior de Agricultura de Lavras, Lavras.

Triller C (1994) Previsão do potencial genético de cruzamentos em soja pela geração $F_{3}$. M.S. thesis, Universidade Estadual de Londrina/ Empresa Brasileira de Pesquisa Agropecuária/ Instituto Agronômico do Paraná, Londrina.

Vencovsky R (1987) Herança quantitativa. In: Paterniani E and Viegas G (eds) Melhoramento e produção de milho no Brasil. Fundação Cargill, Campinas, pp 137-209.

Vencovsky R and Barriga P (1992) Genética biométrica no fitomelhoramento. Sociedade Brasileira de Genética, Ribeirão Preto. 